\title{
Możliwości ksztaltowania optymalnego zarysu pojazdu tramwajowego w świetle aktualnie obowiązujących przepisów bezpieczeństwa jazdy, komfortu pasażerów i ergonomii pracy motorniczego
}

\begin{abstract}
Artykut jest poświęcony studium możliwości ksztattowania optymalnego zarysu pojazdu tramwajowego $w$ oparciu o obowiqzujace przepisy $w$ zakresie skrajni kinematycznej pojazdu tramwajowego oraz skrajni budowli. Artykut stanowi dalsza kontynuację artykutu „Możliwości ksztattowania optymalnego zarysu pojazdu tramwajowego” i przedstawiono $w$ nim problematykę doboru maksymalnej szerokości pojazdu tramwajowego, czynniki zwiqzane z ksztaltowaniem części czołowej oraz parametry techniczno-ekonomiczne oceny wspótczesnych konstrukcji pojazdów tramwajowych.

Artykut powstat w ramach projektu badawczego $n r N 509$ 03531/2367, finansowanego

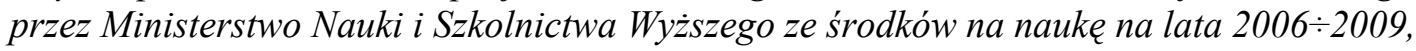
pt.: „,Metodyka wyznaczania kinematycznego zapotrzebowania przestrzeni oraz luzów bezpieczeństwa dla pojazdów tramwajowych, celem ustalenia optymalnego zarysu pojazdu”.
\end{abstract}

\section{Maksymalna szerokość pojazdu tramwajowego}

Maksymalna szerokość pojazdu tramwajowego wynika bezpośredniego obliczenia różnicy pomiędzy dopuszczalnym zarysem odniesienia skrajni kinematycznej i zwężeniami wewnętrznymi $\mathrm{E}_{\mathrm{i}}$ oraz zewnętrznymi $\mathrm{E}_{\mathrm{a}}$. Wzory na zwężenia w przepisach krajowych są wymienione $\mathrm{w}$ normie PN-K-92008:1998 [7] i PN-K-92008/Ap1:1998 [8]. Jednym z zasadniczych celów jest między innymi osiagnnięcie maksymalnej szerokości pojazdu tramwajowego na możliwie jego największej długości. Jak wynika $\mathrm{z}$ [2] przy pierwszych tramwajach z obniżoną podłogą typu VÖV realizowana szerokość pojazdu tramwajowego wynosiła 2,4 m względnie $2,3 \mathrm{~m}$. Łącznie zbudowano trzy prototypy tramwajów typu VÖV tzn. Düsseldorf/München o szerokości 2,4 m ( o długości 20,19 $\mathrm{m}$ ), Mannheim/Ludwigshafen o szerokości 2,3 m ( o długości 26,69 m), Bonn/Düsseldorf o szerokości 2,4 m ( o długości 20,19 m). Szerokość ta została utrzymana przy współczesnych tramwajach niskopodłogowych typu NGT8D użytkowanych przez BSVAG (Braunschweig)-rok budowy 2007 (szerokość 2,3 m przy długości 29,4 m oraz układzie osi Bo'2'2' Bo'), typu ST14 użytkowanych przez HEAG (Darmstadt)rok budowy 2007 (szerokość 2,4 m przy długości 27,728 m oraz układzie osi Bo'2'2' Bo') oraz typu NGT8G użytkowanych przez GVB (Gera)-rok budowy 2006/2007 (szerokość 2,4 m przy długości 27,658 m oraz układzie osi Bo'2'2'Bo') [2]. Wynika z tego, że założona szerokość pojazdu jest dalej realizowana i potwierdza to słuszność założeń konstrukcyjnych, opracowanych w latach 80-tych dla tramwajów z obniżoną podłogą typu VÖV. Istotnym czynnikiem ograniczającym szerokość wagonu we wszystkich przypadkach było zapewnienie przejezdności przez minimalny promień łuku toru, który wynosi w przypadku rozpatrywanych tramwajów odpowiednio $20 \mathrm{~m}$, $20 \mathrm{~m}$ i $18 \mathrm{~m}$. Szerokość pojazdów tramwajowych wpływa na szerokość miejsc siedzących oraz korytarzy przejściowych, co jest elementem komfortu jazdy pasażerów. $\mathrm{Z}$ ww. trzech pojazdów tramwajowych produkowanych w latach 2006-2007 parametry są przedstawione w tabeli 1 .

Bardzo ważnym parametrem mającym wpływ na komfort jazdy pasażerów jest również szerokość w zakresie przegubu tramwajowego ( niem. „Faltenbalg und Übergang im Gelenkbereich"). Przykład takiego przejścia dla tramwaju niskopodłogowego typu VÖV jest przedstawiony na rys. 11 .

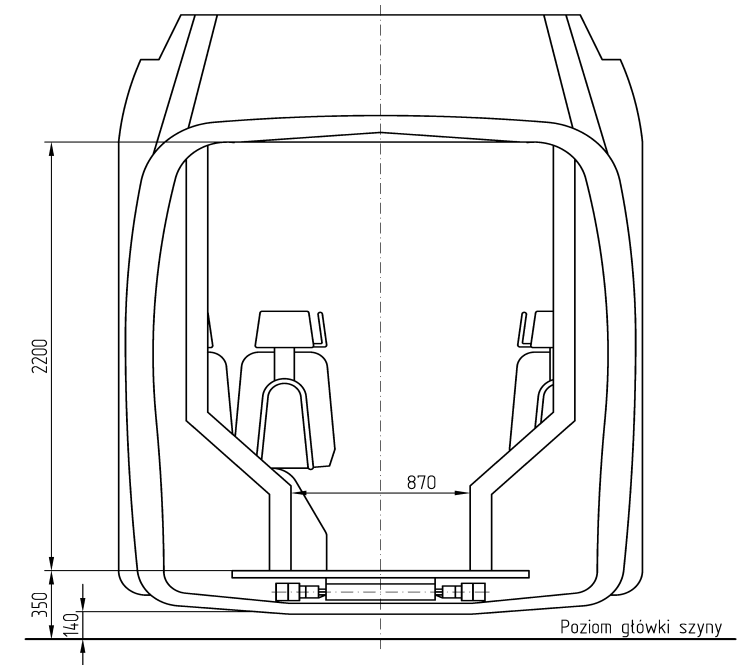

Rys.11. Przykład przejścia w strefie przegubu dla tramwaju niskopodłogowego typu VÖV 
Parametry szerokościowe współczesnych tramwajów niskopodłogowych

Tabela 1

\begin{tabular}{|c|c|c|c|c|}
\hline \multirow{2}{*}{ L.p. } & \multicolumn{2}{|c|}{ Typ tramwaju } & \multirow{2}{*}{$\begin{array}{c}\text { Szerokość korytarza przej- } \\
\text { ściowego pomiędzy podwój- } \\
\text { nymi siedzeniami } \\
{[\mathrm{mm}]}\end{array}$} & \multirow{2}{*}{$\begin{array}{l}\text { Szerokość miejsca siedzącego } \\
{[\mathrm{mm}]}\end{array}$} \\
\hline & Oznaczenie & Użytkownik/miasto & & \\
\hline 1. & NGT8D & BSVAG/Braunschweig & 585 & 425 \\
\hline 2. & ST14 & HAEG/Darmstadt & 468 & 450 \\
\hline 3. & NGT8G & GVB/Gera & 468 & 450 \\
\hline
\end{tabular}

Maksymalna szerokość pojazdu tramwajowego ma ścisły związek z konstrukcją jego wnętrza ( niem.,, Innenausbau” lub „Innenraum”). Charakterystyczną cechą wnętrza, tramwaju jest przechodnia podłoga o wysokości $350 \mathrm{~mm}$ ( niem. ,durchgängiger Fußboden"), co umożliwia zastosowanie układów biegowych z kołami o małych średnicach oraz przegubów o bardzo niskiej wysokości zabudowy. Za pomocą przestrzennego rozdzielenia wzdłużnej i poprzecznej osi obrotu przegubu gwarantuje się dodatkowo bardzo dużą szerokość przejścia dla pasażerów, która jest ograniczona jedynie na wysokości kolan pasażerów. Nowoczesny pojazd tramwajowy musi gwarantować możliwość wjazdu i miejsce w przedniej części dla osoby niepełnosprawnej na wózku inwalidzkim. Dodatkowo dochodzi warunek zapewnienia miejsca dla wózka dziecięcego, usytuowanego najlepiej za kabiną motorniczego. Koncepcja wnętrza pojazdu tramwajowego orientuje się na technologię autobusów, które cechują się małą masą własną.

\section{Ksztaltowanie części czołowej tramwaju nisko- podłogowego}

W związku ze zwężeniami zewnętrznymi $\mathrm{E}_{\mathrm{a}}$, które ograniczają zarys zewnętrzny pojazdu tramwajowego w stosunku do zarysu odniesienia występuje problem kształtowania części czołowej pojazdu tramwajowego (rys.12).
Ze schematycznego rys.12 wynika, że ostateczny kształt pojazdu tramwajowego, jakiego nabiera on w fazie projektowania i produkcji $\mathrm{w}$ wyniku uwzględnienia zwężeń wewnętrznych $\mathrm{E}_{\mathrm{i}}$ oraz zewnętrznych $\mathrm{E}_{\mathrm{a}}$ jest przedstawiony na rys.13, który zawiera przykładową konstrukcję tramwaju niskopodłogowego typu NGT8D dla Braunschweigu.

Jak widać z rys.13 największy skutek zwężeń obejmuje czoło pojazdu tramwajowego, w którym znajduje się kabina motorniczego (niem., Führerraum" lub „Fahrerraum”). W związku czoło kabiny motorniczego nabiera kształtu ograniczonego krzywą paraboliczną zwężeń zewnętrznych. Kształt ten utrudnia zadanie konstruktorom, technologom i producentom, ale coraz więcej wytwórni podejmuje to wyzwanie. Taki kształt czoła pojazdu tramwajowego ułatwia optymalne rozmieszczenie urządzeń obsługi na pulpicie motorniczego oraz ergonomię stanowiska pracy (dobra widoczność, możliwość dobrej obsługi stanowiska pracy przez ergonomiczne rozmieszczenie elementów obsługi, optymalna konstrukcja miejsca siedzącego dla motorniczego). W tym przypadku szczególny nacisk położono również na dostępność napędu wycieraczek, posiadającego budowę kompaktową, usytuowanego na zewnattrz pojazdu i łatwo wymienialnego. W nowych rozwiązaniach kabin motorniczych szafa z urządzeniami elektrycznymi znajduje się z tyłu za siedzeniem motorniczego, przy czym drzwi do niej znajdują się w

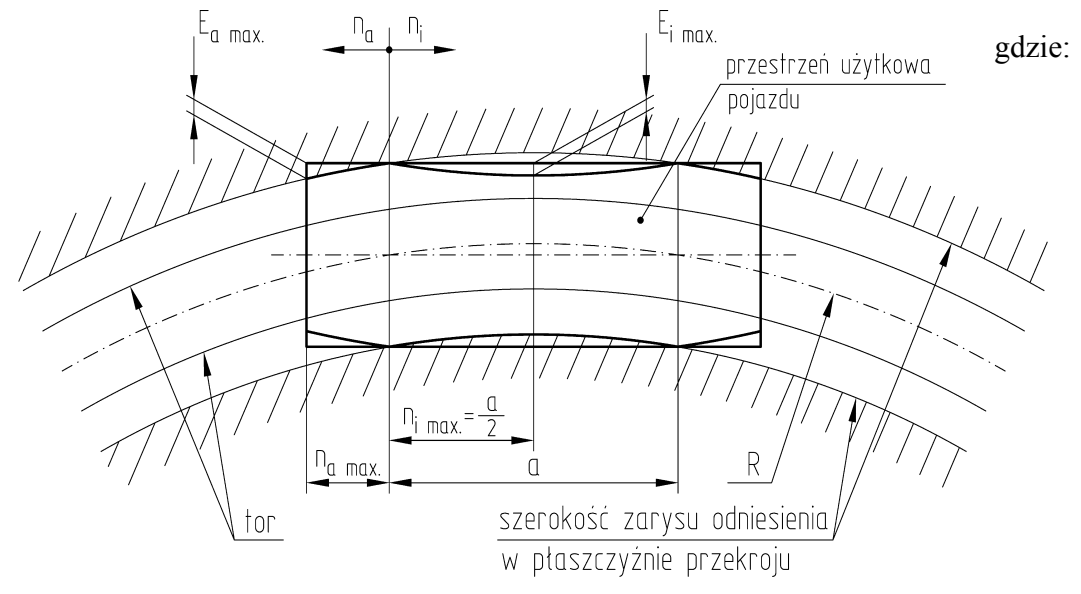

Rys.12. Zwężenia zewnętrzne $\mathrm{E}_{\mathrm{a}}$ oraz zwężenia wewnętrzne $\mathrm{E}_{\mathrm{i}}$ wpływające na ostateczny zarys pojazdu tramwajowego
R- promień łuku toru

a- baza pojazdu ( rozstaw czopów skrętu pomiędzy wózkami, środkami wózków lub pomiędzy skrajnymi zestawami kołowymi w przypadku wózków jednoosiowych)

$\mathrm{n}_{\text {imax }}{ }^{-}$odległość od czopa skrętu, umownego środka wózka ( pojazdy wózkowe) lub osi zestawu kołowego w kierunku wewnętrznym, dla którego zwężenia wewnętrzne $\mathrm{E}_{\text {imin }}$ przyjmują wartości maksymalne

$\mathrm{n}_{\text {amax }}$ - odległość od czopa skrętu, umownego środka wózka ( pojazdy wózkowe) lub osi zestawu kołowego w kierunku wewnętrznym, dla którego zwężenia wewnętrzne $\mathrm{E}_{\mathrm{amax}}$ przyjmują wartości maksymalne 

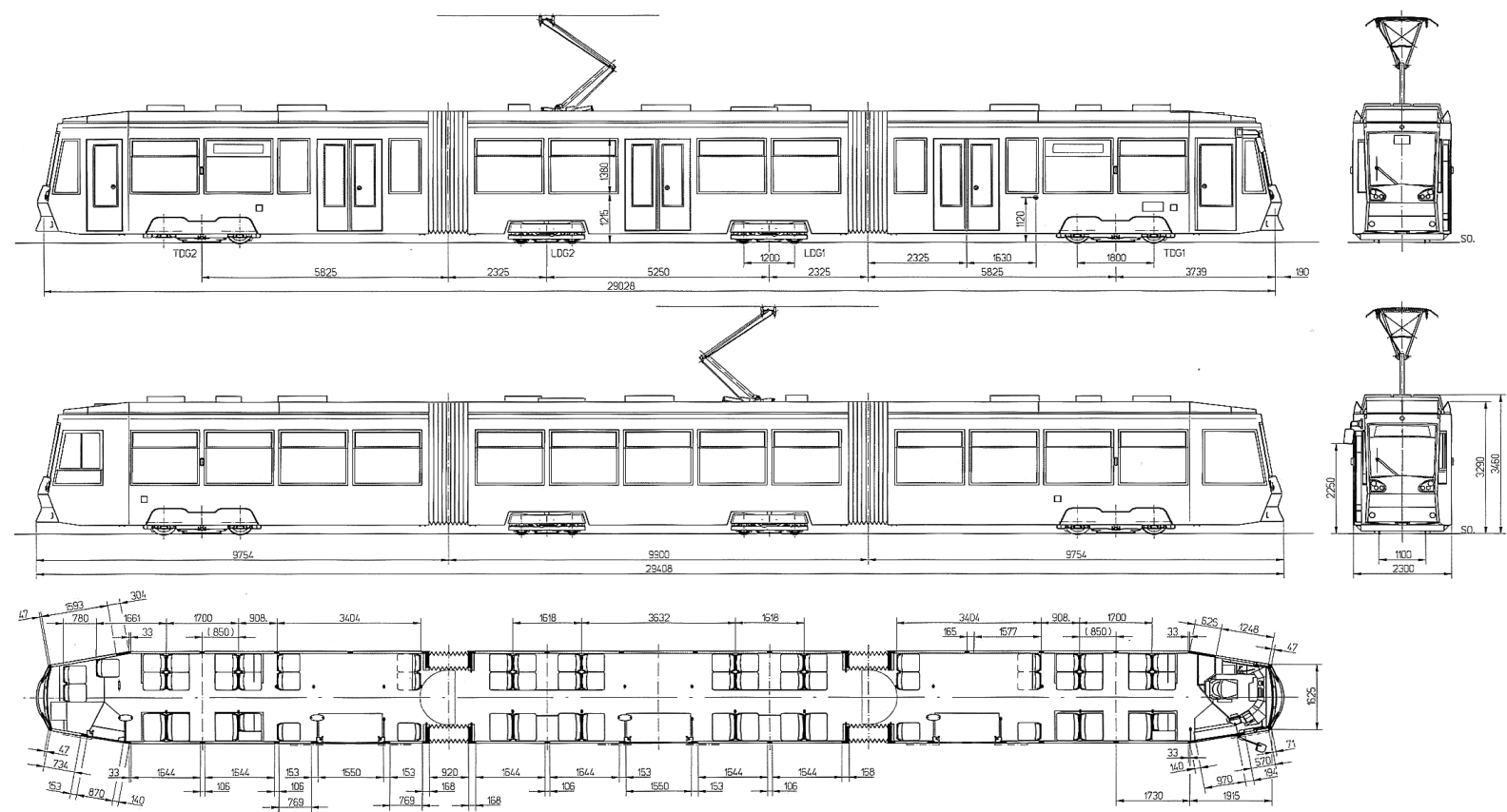

Rys.13. Ogólny widok tramwaju niskopodłogowego ze zwężonym kształtem części czołowej typu NGT8D dla przedsiębiorstwa BSVAG w Braunschweigu (Niemcy) [1]

płaszczyźnie ścianki działowej oddzielającej kabinę maszynisty od pomieszczenia dla pasażerów. W nowatorski sposób rozwiązano również sprawę napowietrzenia kabiny motorniczego, które jest zasysane bez wywoływania przeciagów przez boczne, odchylne szyby w kierunku szyby czołowej. Przykładowy kształt czoła pojazdu tramwajowego wraz z rozmieszczeniem elementów obsługi na pulpicie motorniczego niskopodłogowego typu VÖV jest przedstawiony na rys. 14.

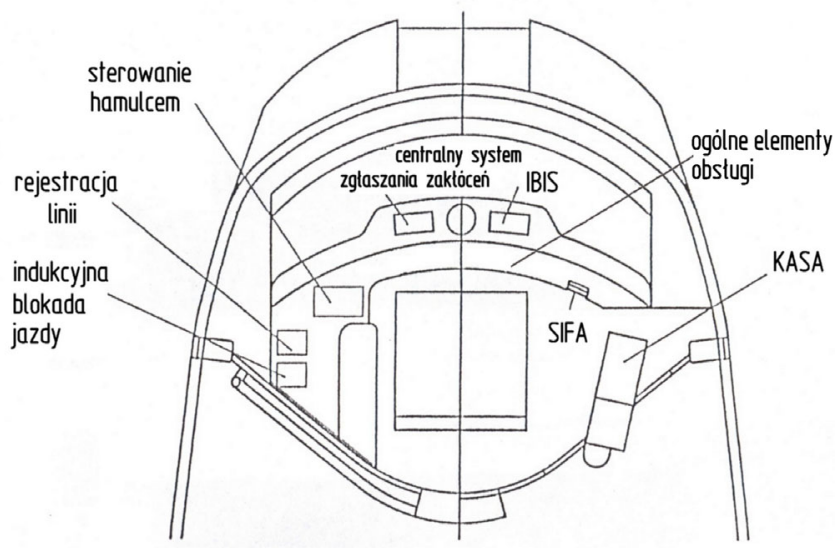

Rys.14. Rozmieszczenie urządzeń w kabinie motorniczego dla tramwaju niskopodłogowego typu VÖV
Z podanego przykładu można wyciagnąć wniosek, że maksymalne zwężenia wewnętrzne są kryterium doboru efektywnej szerokości pojazdu tramwajowego dla przestrzeni przeznaczonej do korzystania przez pasażerów, natomiast dla kabiny motorniczego taka ich wielkość zwężeń zewnętrznych, która może być do zrealizowania przez producenta $\mathrm{w}$ aspekcie technologicznym oraz ekonomicznym. Rys.13 i rys.14 podaja przykład ewolucji w podejściu do projektowania pojazdów tramwajowych. W przypadku tradycyjnych tramwajów w Polsce i Europie produkowanych do lat osiemdziesiątych dążąc do uproszczenia konstrukcji wymiary gabarytowe kabiny motorniczego odpowiadały wymiarom części środkowej, co powodowało znaczne zmniejszenie jej długości, a zatem w konsekwencji znaczne ograniczenie możliwości optymalnego kształtowania stanowiska pracy. W obecnych konstrukcjach kształt pojazdów tramwajowych jest dobierany w oparciu o spełnienie warunku:

gdzie:

$$
\mathrm{E}_{\mathrm{amax}}>\mathrm{E}_{\text {imax }}
$$

$\mathrm{E}_{\mathrm{amax}}$ - maksymalne zwężenie zewnętrzne

$\mathrm{E}_{\text {imax }}-$ maksymalne zwężenie wewnętrzne

Maksymalne zwężenie zewnętrzne $E_{a \max }$ jest przyjmowane jako dopuszczalne $\mathrm{z}$ punktu widzenia użytkowego i technologicznego dla opracowania optymalnego kształtu kabiny motorniczego i czoła pojazdu. Maksymalne zwężenie wewnętrzne $E_{\text {imax }}$ jest przyjmowane do ustalenia dopuszczalnej szerokości pojazdu w części przeznaczonej dla pasażerów. Wraz z 
nowym sposobem kształtowania kabin motorniczych oraz czół pojazdów tramwajowych pojawiła się okazja przemyślenia no nowo konstrukcji elementów pochłaniająco-zderznych, zabezpieczających konstrukcję tramwaju przed uszkodzeniami przy zderzeniach. W tym przypadku zaproponowano budowę modułową urządzeń tego typu, których przykładowe konstrukcje zostały przedstawione na rys. 15 i rys. 16 .
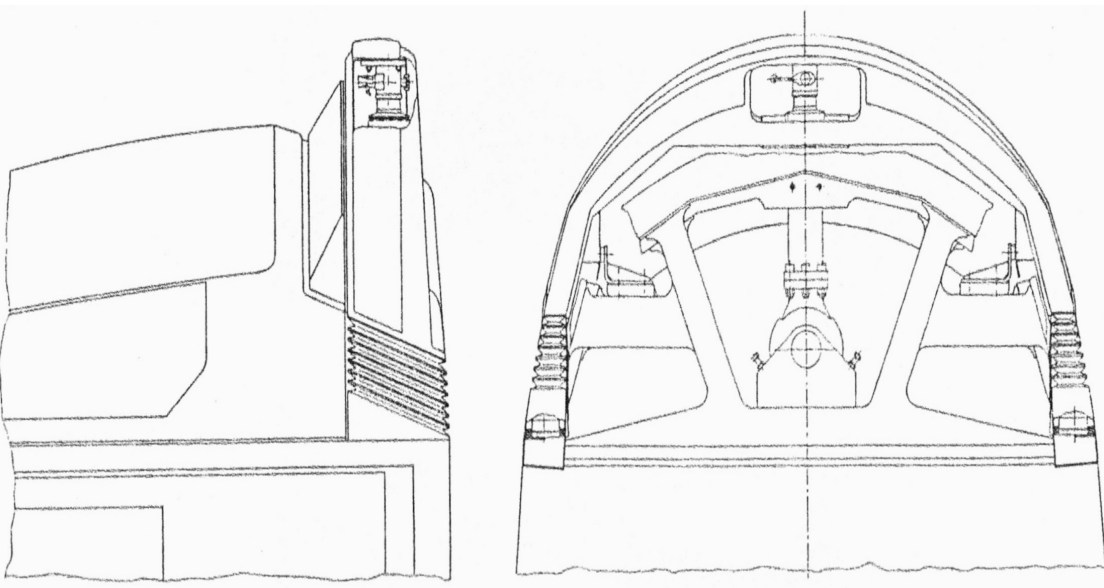

Rys.15. Element pochłaniająco-zderzny wkomponowany (niem. „Stoßstange mit Wechseladapter") w postaci do nowoczesnego kształtu czoła pojazdu tramwajowego niskopodłogowego typu VÖV

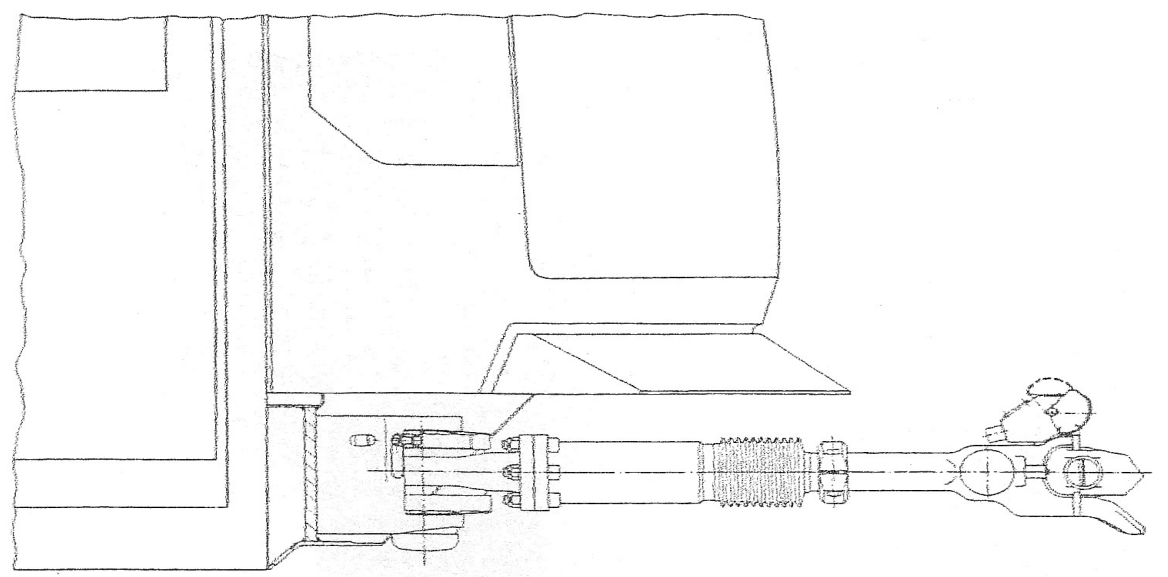

Rys.16. Sprzęg automatyczny (niem.,,Automatische Kupplung”) dla tramwaju niskopodłogowego typu VÖV

Jak wynika z rys. 15 i 16 istotnym elementem ograniczającym konstrukcję urządzeń pochłaniającozderznych ( niem.,,Stoßverzehreinrichtung”) w takiej konfiguracji jest wymiar dolnego zarysu skrajni budowli oraz zwężenia zewnętrzne $\mathrm{E}_{\mathrm{a}}$. Modułowa budowa umożliwia zastosowanie urządzeń innych producentów, pod warunkiem utrzymania zasady zamienności. Urządzenia pochłaniająco-zderzne, przedstawione na rys.15 i 16 gwarantuja przy prędkości nabiegania $3 \div 4 \mathrm{~m} / \mathrm{s}(10,8 \div 14,4 \mathrm{~km} / \mathrm{h})$ brak odkształceń trwałych, natomiast przy prędkościach $6 \div 8 \mathrm{~m} / \mathrm{s} \quad(21,6 \div 28,8$ $\mathrm{km} / \mathrm{h}$ ) moga powstać lekkie odkształcenie trwałe w częściach urządzeń pochłaniająco-zderznych, których wymiana nie stwarza większych trudności.

\section{Parametry techniczne oceny konstrukcji pojaz- dów tramwajowych}

Jak wynika z [1] do oceny konstrukcji stosuje się ilości miejsc siedzących, stojących oraz wskaźniki, które dla trzech przykładowych tramwajów są przedstawione w tabeli 2 .

Z przedstawionych wskaźników jednostkowych ( niem. ,spezifische Zahlen") tzn. masa własna/powierzchnia użytkowa, masa własna/miejsce siedzące i moc/masa własna w pierwszych dwóch przypadkach mniejsza wartość wskaźnika, a w przypadku trzeciego większa wartość świadczy na korzyść konstrukcji. Należy jednak pamiętać, że ww. wskaźników nie można rozpatrywać oddzielnie a razem $\mathrm{i}$ razem $\mathrm{z}$ potencjałem miejsc siedzących oraz stojących.

\section{Parametry ekonomiczne oceny konstrukcji pojaz- dów tramwajowych}

Podstawowym parametrem ekonomicznym oceny konstrukcji tramwajowych jest jednostkowy wskaźnik ceny jednego metra kwadratowego użytkowej tramwaju. Przykładowe ceny pojazdów zamówionych pomiędzy 15.10.2006:15.10.2007 przedstawiono $\mathrm{W}$ tabeli 3.

Jak wynika $\mathrm{z}$ tabeli 3 najkorzystniejszy wskaźnik cenowy posiada tramwaj typu „Classic” dla Bremen 21319 euro $/ \mathrm{m}^{2}$, przy ogólnej cenie wynoszącej 2,1 miliona Euro.

Na uwagę zasługuje relatywnie duża szerokość pojaz$\mathrm{du}$, wynosząca aż $2,65 \mathrm{~m}$. Pozostałe tramwaje posiadają szerokość $2,3 \div 2,4 \mathrm{~m}$, co potwierdza trafność prac studialnych przeprowadzonych przy projektowaniu tramwajów niskopodłogowych typu VÖV. Najniższą cenę całkowita posiada tramwaj typu „Classic” dla Krakowa wynoszącą tylko 1,75 miliona euro, przy jednostkowym wskaźniku cenowym 28044 euro $/ \mathrm{m}^{2}$. Jest to cena zdecydowanie mniejsza od tramwaju typu „Tango" dla Basel, wynoszącej 3 miliony euro. Tramwaje dla Krakowa posiadają jednak mniejszą przestrzeń użytkową wynoszącą $26 \times 2,4 \mathrm{~m}$ w porównaniu do tych dla Basel- 44,61×2,3 m. Zdecydowanie 
Parametry techniczne oceny konstrukcji pojazdów tramwajowych

Tabela 2

\begin{tabular}{|c|c|c|c|c|c|c|c|c|}
\hline \multirow{2}{*}{ L.p. } & \multicolumn{2}{|c|}{ Typ tramwaju } & \multirow{2}{*}{$\begin{array}{c}\text { Ilość } \\
\text { miejsc } \\
\text { siedzących }\end{array}$} & \multirow{2}{*}{$\begin{array}{c}\text { Ilość } \\
\text { miejsc } \\
\text { stojących }\end{array}$} & \multirow{2}{*}{$\begin{array}{c}\text { Ilość } \\
\text { miejsc } \\
\text { łącznie }\end{array}$} & \multirow{2}{*}{$\begin{array}{c}\text { Masa } \\
\text { własna/ } \\
\text { Pow. } \\
{\left[\mathrm{kg} / \mathrm{m}^{2}\right]}\end{array}$} & \multirow{2}{*}{$\begin{array}{c}\text { Masa/ } \\
\text { miejsce } \\
\text { siedzące } \\
{[\mathrm{kg}]}\end{array}$} & \multirow{2}{*}{$\begin{array}{c}\text { Moc/ } \\
\text { masa } \\
\text { własna } \\
{[\mathrm{kW} / \mathrm{t}]}\end{array}$} \\
\hline & Oznaczenie & Użytkownik/miasto & & & & & & \\
\hline 1. & NGT8D & BSVAG/Braunschweig & 66 & 107 & 173 & 638 & 524 & 12,1 \\
\hline 2. & ST14 & HAEG/Darmstadt & 68 & 93 & 161 & 600 & 500 & 11,1 \\
\hline 3. & NGT8G & GVB/Gera & 72 & 87 & 159 & 600 & 472 & 11,1 \\
\hline
\end{tabular}

\section{Zestawienie cen całkowitych i jednostkowych wskaźników cenowych dla tramwajów zamówionych przez poszczególne miasta w okresie $15.10 .2006 \div 15.10 .2007$}

Tabela 3

\begin{tabular}{|c|c|c|c|c|c|c|}
\hline L.p. & System & Model & $\begin{array}{c}\text { Ilość zamó- } \\
\text { wień }\end{array}$ & $\begin{array}{c}\text { Długość× } \\
\text { szerokość }\end{array}$ & $\begin{array}{c}\text { Cena W Mil } \\
\text { EUR }\end{array}$ & $\begin{array}{c}\text { Cena } / \mathrm{m}^{2} \mathrm{~W} \\
\text { EUR } / \mathrm{m}^{2}\end{array}$ \\
\hline 1. & Fland De Ljn & Hermelijn & 10 & $29,1 \times 2,3$ & 2,1 & 31400 \\
\hline 2. & Drezno & Classic & 10 & $30 \times 2,3$ & 2,2 & 31900 \\
\hline 3. & Basel & Tango & $4+56$ & $44,61 \times 2,3$ & 3 & 29240 \\
\hline 4. & AnT/BVB & Citadis 302 & 17 & $32 \times 2,4$ & 2,65 & 34505 \\
\hline 5. & Touluse & Citadis 302 & 18 & $32,2 \times 2,4$ & 2,38 & 30842 \\
\hline 6. & Berlin & Berlin & $4+206$ & $30 \times 2,4$, & 2,71 & 32261 \\
\hline 7. & Kraków & Classic & 24 & $26 \times 2,4$ & 1,75 & 28044 \\
\hline 8. & Dortmund & Classic & 47 & $30 \times 2,4$ & 2,13 & 29600 \\
\hline 9. & Innsbruck & Cityrunner & $22+10$ & $27,6 \times 2,4$ & 2,32 & 35000 \\
\hline 10. & Palermo & Cityrunner & 17 & $32,5 \times 2,4$ & 2,896 & 37153 \\
\hline 11. & Bremen & Classic & 10 & $35,4 \times 2,65$ & 2,1 & 21319 \\
\hline 12. & Darmstadt & MGT8 & 6 & $27,28 \times 2,4$ & 2,16 & 33000 \\
\hline 13. & Augsburg & Outlock & $10+20$ & $40 \times 2,3$ & 2,96 & 32246 \\
\hline 14. & Drezno & Classic & 10 & $30 \times 2,3$ & 2,2 & 31884 \\
\hline 15. & Graz & Variobahn & 45 & $27,1 \times 2,3$ & 2,17 & 34814 \\
\hline 16. & Lyon & Citadis 302 & 13 & $32,4 \times 2,4$ & 2,1 & 27000 \\
\hline 17. & Rhein- & Variobahn & 8 & $42,8 \times 2,4$ & & 29745 \\
& Neckar & & 8 & $32,2 \times 2,4$ & 2,74 & \\
\hline & & & 3 & $42,8 \times 2,4$ & & \\
\hline
\end{tabular}

najwyższy jednostkowy wskaźnik cenowy osiagnął tramwaj typu „Cityrunner” dla Innsbrucku wynoszący 35000 euro $/ \mathrm{m}^{2}$, przy bardzo porównywalnych parametrach przestrzennych jak dla Krakowa tzn. $27,6 \times 2,4 \mathrm{~m}$.

\section{Wnioski}

Na podstawie przeprowadzonych analiz można stwierdzić, że ustalenie zarysu pojazdu w oparciu o obliczenia skrajni posiada kluczowe znaczenie. Obliczenia te muszą z jednej strony zagwarantować bezpieczeństwo eksploatowanego pojazdu ( brak kolizji podczas mijania się pojazdów oraz $\mathrm{z}$ budowlami stałymi we wszystkich możliwych stanach eksploatacyjnych ) jak również zaprojektowanie takiego pojazdu, który jest w stanie sprostać współczesnym wymaganiom rynkowym. Sprowadza się to do osiagnięcia optymalnego kształtu pojazdu w zakresie wysokości podłogi ( ułatwiony dostęp przy wsiadaniu i wysiadaniu osób niepełnosprawnych, w starszym wieku oraz z dziećmi i bagażami), wysokości całkowitej pojazdu ( umieszczenie na dachu urządzeń pomocniczych), szerokości pudła ( komfort podczas jazdy pasażerówszerokość miejsc siedzących, szerokość korytarzy przejściowych pomiędzy miejscami siedzącymi oraz $\mathrm{w}$ rejonie przegubu). Są to najczęściej pojawiające się wymagania rynkowe, które muszą spełnić pojazdy tramwajowe, aby mogły sprostać w rywalizacji z innymi środkami transportu. Jest to poważne wyzwanie dla konstruktorów pojazdów tramwajowych, którzy muszą podejmować decyzje w oparciu o coraz bardziej dokładne metody obliczeniowe, dotyczące skrajni kinematycznej. Metody obliczeniowe powinny być weryfikowane poprzez metody doświadczalne, jak np. pomiar współczynnika pochylania i pomiary na trasie, które mają sprawdzić rzeczywistą odległość pojazdu tramwajowego od budowli stałych. Analizując współczesne konstrukcje pojazdów tramwajowych, można stwierdzić że „każdy milimetr wolnej przestrzeni”, będącej do dyspozycji konstruktora będzie na pewno ", zagospodarowany". Problemów tych nie da się roz - 
wiązać bez pomocy infrastruktury, jak np. dostosowanie wysokości peronów przy wsiadaniu i wysiadaniu pasażerów. Wyrób finalny podlega weryfikacji cenowej, gdzie można sprawdzić w oparciu o ustalone wskaźniki jakość wyrobu finalnego. Na uwage zasługuje na pewno minimalizacja masy własnej w zakresie możliwym do uzyskania przy jednoczesnym zapewnieniu możliwie największej powierzchni użytkowej pojazdu tramwajowego. Istotny postęp w dziadzienie rozwoju pojazdów tramwajowych jaki dokonał się od czasu powstania pierwszego tramwaju niskopodłogowego w Grenoble jest wynikiem poważnej rywalizacji $\mathrm{z}$ transportem samochodowym. Coraz więcej potencjalnych pasażerów posiada własny samochód osobowy i przestaje być zakładnikiem transportu miejskiego ( ang.,,captive riders") Poważna rewolucja rozwojowa wystąpiła $\mathrm{w}$ zakresie projektowania kabiny motorniczego i czoła pojazdów tramwajowych w związku ze wzrastającymi wymaganiami w zakresie ergonomii i bezpieczeństwa oraz higieny pracy ( standardem staje się wyposażenie kabiny motorniczego $\mathrm{w}$ urządzenie klimatyzujące). Kolejnym wyzwaniem jest zwiększenie wymagań $\mathrm{w}$ zakresie pasywnego bezpieczeństwa pojazdów tramwajowych zapewniającego zabezpieczenie konstrukcji przed skutkami przypadkowych zderzeń, polegającego na koniczności zainstalowania elementów zderzno-pochłaniających, wymagających dodatkowej przestrzeni dla ich zabudowy.

\section{Literatura}

[12] Sobaś M.: Możliwości ksztattowania optymalnego zarysu pojazdu tramwajowego (1). Pojazdy Szynowe $\mathrm{Nr} 1 / 2008$ 